\title{
EKOLOGI BUDAYA SEBAGAI WAWASAN POKOK DALAM PENGEMBANGAN MASYARAKAT UNTUK PEMBANGUNAN BERKELANJUTAN DI INDONESIA
}

\author{
1 Gian Nova Sudrajat Nur \\ Fakultas Dakwah UIN Sultan Maulana Hasanuddin Banten \\ *Corresponding Author email: gian.nova@uinbanten.ac.id
}

\begin{tabular}{ll}
\hline & Abstrak \\
\cline { 2 - 3 } $\begin{array}{l}\text { Diterima : } \\
\text { Bulan Januari }\end{array}$ & $\begin{array}{l}\text { Tulisan ini mendiskusikan kearifan lokal dari masyarakat-masyarakat lokal di Indonesia } \\
\text { dalam pengelolaan sumber daya alam yang berwawasan lingkungan sebagai }\end{array}$ \\
& $\begin{array}{l}\text { implementasi pembangunan yang berkelanjutan. Tujuan dari tulisan ini adalah } \\
\text { memberikan gambaran mengenai bentuk-bentuk pengelolaan sumber daya alam dan }\end{array}$ \\
Diterbitkan : & penanggulangan permasalahan lingkungan yang didasarkan kepada kearifan lokal sebagai \\
Bulan Februari & wawasan untuk kegiatan pengembangan masyarakat. Penelitian ini berbentuk deskriptif \\
kualitatif dengan metode deskriptif analitis dengan menggunakan pendekatan teori & ekologi budaya melalui studi literatur. Dari hasil penelitian ini, diketahui bahwa nilai- \\
& nilai kebudayaan di Indonesia cenderung ekosentris dan biosentris, sehingga dapat \\
Keyword: & dikatakan sebagai deep ecology (ekologi yang dalam/pekat). Selain itu, ditunjukkan juga \\
Ekologi Budaya, & nilai-nilai kebudayaan mengatur pengelolaan sumber daya alam dengan arif. Tulisan ini \\
Pengembangan & juga menunjukkan bahwa kearifan lokal sebagai ekologi budaya merupakan wawasan \\
Masyarakat, & penting dalam kegiatan pengembangan masyarakat karena tidak hanya membentuk \\
Pembangunan & kemandirian dan menciptakan kesejahteraan. Lebih dari itu, ekologi budaya merupakan \\
Berkelanjutan & pengejawantahan dari pembangungan berkelanjutan.
\end{tabular}

\section{PENDAHULUAN}

Paradigma pembangunan di Indonesia terus berkembang dan senantiasa mengalami perubahan. Paradigma pertumbuhan ekonomi dari dulu sampai dengan saat ini tetap menjadi sorotan utama sebagai tolak ukur kemajuan ekonomi di Indonesia. Pertumbuhan ekonomi sendiri dapat dikatakan sebagai sebuah paradigma yang menekankan pada pendapatan per kapita sebuah negara. Hal tersebut terfokus kepada produktivitas sebuah negara dengan harapan dapat terwujudnya trickle down effect (usaha besar dapat memberikan dampak dengan cara membantu usahausaha kecil untuk berkembang). Akan tetapi, pada kenyataannya prinsip tersebut tidak berjalan dengan baik yang seharusnya menetes/memberikan dampak ke bawah menjadi muncrat ke atas, sehingga menimbulkan kesenjangan ekonomi dan sosial yang lebih luas. Salah satunya penguasaan akses dalam kegiatan ekonomi. Hanya pihak-pihak tertentu yang melakukan monopoli dan oligopoli ekonomi. Selain itu, kegiatan yang dilakukan menciptakan distorsi atau krisis lingkungan. Keuntungan finansial menjadi tujuan utama tanpa menghiraukan akan kesinambungan sumber daya alam yang ada.

Berdasarkan hal tersebut, muncul paradigma atau strategi pembangunan people centered development (pembangunan yang berpusat kepada manusia yang dalam hal ini masyarakat lokal).
Menurut Korten yang dikutip oleh Tjokrowinoto (1999) dalam Jamaludin (2016: 22), paradigma ini dapat memberikan tempat yang penting bagi prakarsa dan keragaman lokal, serta menekankan pentingnya masyarakat lokal yang mandiri. Manajemen pembangunannya mengubah peranan birokrasi pemerintah dari merencanakan dan melaksanakan pembangunan untuk rakyat, menjadi aktor dalam menciptakan kondisi yang menimbulkan kemandirian rakyat. Dengan kata lain, menempatkan pemerintah sebagai katalis dalam mempercepat proses pembangunan yang berpusat kepada kemandirian lokal (Tjokrowinoto, 1999 dalam Jamaludin, 2016: 22). Paradigma ini berpandangan bahwa seharusnya masyarakat bukan hanya sebagai objek dari pembangunan, melainkan subjek dari pembangunan itu sendiri. Oleh karena itu, seharusnya mereka diberikan kuasa untuk melakukan pengelolaan sumber daya yang ada dengan dukungan dari pemerintah sebagai katalisator, sehingga tercipta pemerataan ekonomi yang berdampak pada kesejahteraan masyarakat.

Kemandirian masyarakat merupakan bagian penting bagi pembangunan. Hal tersebut tidak hanya berdampak positif bagi masyarakat, melainkan juga kepada negara. Menurut Gea (2002: 146) kemandirian merupakan kemampuan seseorang untuk mewujudkan keinginan dan kebutuhan hidupnya dengan kekuatan 
sendiri. Berdasarkan hal tersebut, dapat diasumsikan bahwa dengan kemandirian, masyarakat mampu memberikan kesejahteraan pada dirinya sendiri. Yang berarti, bahwa masyarakat yang mandiri akan memberikan kontribusi pada peningkatan produktivitas sebuah negara.

Oleh karena itu, diperlukan intervensiintervensi dari pihak luar untuk menciptakan kemandirian masyarakat. Salah satu intervensi tersebut adalah kegiatan pengembangan masyarakat atau dikenal juga dengan model pemberdayaan masyarakat. Model tersebut merupakan kegiatan yang menitikberatkan kepada pembangunan manusia itu sendiri. Artinya, pendekatan yang dilakukan menempatkan masyarakat sebagai pusat pengembangan. Suharto (2009: 99) mengatakan, bahwa konsep pemberdayaan masyarakat membangun paradigma baru dalam pembangunan, yaitu bersifat people centered (berpusat kepada manusia), participatory (partisipatif), empowering (memberdayakan), dan sustainable (berkesinambungan). Oleh karena itu, kegiatan pengembangan masyarakat dengan model pemberdayaan dapat dikatakan sebagai sebuah konsep yang dapat memandirikan masyakarat. Model ini memberikan ruang bagi masyarakat agar turut berpartisipasi secara aktif, sehingga timbul rasa kepemilikan, percaya diri, dan daya/kuasa pada masyarakat. Maka, prinsip berkelanjutan menjadi sebuah keniscayaan meskipun sudah tidak ada intervensi dari pihak luar.

Akan tetapi, model pemberdayaan tersebut akan bertemu dengan sisi paradoksnya ketika masyarakat berhasil menjadi mandiri secara ekonomi, tetapi acuh terhadap lingkungan alam di sekitarnya. Ketika pemberdayaan masyarakat yang didasarkan kepada pengelolaan sumber daya alam, maka harus memperhatikan keberlanjutan alamnya. Adapun jika pengelolaan sumber daya alam tersebut tidak memperhatikan keberlangsungan lingkungan atau menciptakan distorsi dan kerusakan lingkungan, dapat diasumsikan kemandirian masyarakat tersebut tidak akan berlangsung lama, karena sumber daya alam yang dikelolanya rusak. Oleh karena itu, wawasan mengenai ekologi/etika lingkungan menjadi penting dalam kegiatan pemberdayaan.

\section{LANDASAN TEORI}

Pengembangan masyarakat atau dikenal dengan pemberdayaan secara umum dapat dikatakan sebagai upaya untuk meningkatkan kualitas hidup masyarakat. Pemberdayaan sendiri diadaptasikan dari istilah empowerment (memberikan kesempatam, daya kekuatan kepada pihak yang kurang berdaya) yang berkembang di Eropa mulai abad pertengahan. Hal ini terus berkembang hingga di akhir 70-an sampai awal 90-an. Sebagaimana Ife (1995) mengatakan bahwa "Empowerment is a process of helping disadvantaged groups and individual to compete more effectively with other interests, by helping them to learn and use in lobbying, using the media, engaging in political action, understanding how to 'work the system,' and so on". Definisi tersebut dapat diartikan bahwa pemberdayaan (empowerment) merupakan upaya memberikan otonomi, wewenang, dan kepercayaan kepada setiap individu dalam suatu organisasi, serta mendorong mereka untuk kreatif agar dapat menyelesaikan tugasnya sebaik mungkin. Dengan perkataan lain, pemberdayaan masyarakat dapat diartikan sebagai segala bentuk aksi untuk memberikan perubahan kepada masyarakat dari tidak mampu menjadi mampu, sehingga mereka dapat menjadi mandiri.

Kegiatan pemberdayaan sejalan dengan Tujuan Pembangunan Berkelanjutan (TPB) yang dalam Bahasa Inggris dikenal dengan Sustainable Development Goals (SDGs). Pembangunan berkelanjutan merupakan agenda penting dari negaranegara anggota PBB, salah satunya Indonesia. Agenda tersebut dituangkan ke dalam 17 tujuan, yaitu tanpa kemiskinan, tanpa kelaparan, kehidupan sehat dan sejahtera, pendidikan berkualitas, kesetaraan gender, air bersih dan sanitasi layak, energi bersih dan terjangkau, pekerjaan layak dan pertumbuhan ekonomi, industri, inovasi dan infrastruktur, berkurangnya kesenjangan, kota dan pemukiman yang berkelanjutan, konsumsi dan produksi yang bertanggung jawab, penanganan perubahan iklim, ekosistem lautan, ekosistem daratan, perdamaian, keadilan dan kelembagaan yang tangguh, serta kemitraan untuk mencapai tujuan. Dari tujuh belas tujuan tersebut terlihat bahwa tujuan utama dari pembangunan berkelanjutan itu sendiri merupakan upaya untuk membangun manusia dan bertanggung jawab terhadap alam. Hal tersebut searah dengan tujuan dari pemberdayaan, akan tetapi fokus pemberdayaan cenderung kepada kesejahteraan manusianya, sedangkan alam dan lingkungannya belum menjadi bagian penting.

Isu ekologi/lingkungan selalu menjadi diskursus di kalangan intelektual, pemerintah, juga swasta. Di Indonesia sendiri dikenal dengan istilah AMDAL (Analisis Mengenai Dampak Lingkungan). Namun, AMDAL tersebut dapat dikatakan hanya berlaku bagi proyek-proyek besar pemerintah maupun bisnis swasta. Sedangkan, bagi masyarakat sipil (khususnya yang bukan masyarakat adat) hal itu seperti terlupakan atau dapat diasumsikan belum menjadi bagian penting dalam kehidupannya. 
Lingkungan sendiri dianggap sebagai liyan (dalam hal ini diartikan sebagai sesuatu hal yang bukan bagian dari kehidupan manusia), yang bukan bagian dari tanggung jawab manusia. Berbeda dengan masyarakat adat yang masih memegang norma dan nilai-nilai dari kearifan lokal budayanya. Mereka cenderung memperlakukan alam sebagai bagian dari mereka. Ada aturan tidak tertulis yang mengatur pengelolaan sumber daya alam yang ada, dengan tujuan kesinambungan dari pemanfaatan sumber daya alam tersebut. Di sini terlihat bahwa kebudayaan bukan hanya mengatur manusia, melainkan memiliki peran untuk mengatur manusia agar memiliki tanggung jawab terhadap alam sebagai sumber penghidupannya.

Dalam ekologi dikenal istilah ekologi budaya. Ekologi budaya sendiri erat kaitannya antropologi, maka sering juga disebut sebagai antropologi ekologis. Hadirnya konsep ekologi budaya ini merupakan wujud ketidakpuasan para ahli terhadap konsep determinasi dan kementakan lingkungan. Menurut Steward (1955) dalam Abdoellah (2017), interaksi kebudayaan dan lingkungan berlangsung melalui proses adaptasi, terutama inovasi teknologi. Interaksi ini tidak hanya mengubah lingkungan, tetapi juga mengubah asupan energi, materi, dan informasi ke dalam populasi manusia, sehingga kebudayaan menjadi cara hidupnya turut berubah. Di sini terlihat bahwa Steward menganggap kebudayaan merupakan suatu tumpuan di mana manusia bisa beradaptasi terhadap kondisi lingkungan beserta perubahannya.

Steward (1936) dalam Febrianto (2016) menjelaskan secara eksplisit hubungan antara lingkungan dengan kebudayaan ini di dalam bukunya The Economic and Social Primitive Bands. Dalam buku ini Steward menguraikan, mendefenisikan, serta mengembangkan apa yang dia sebut sebagai "ekologi budaya" (cultural ecology). Perspektif ini, menurutnya adalah "differs from the relativistic and neoevolutions 7 conceptions of cultural history, in that it introduces the local environment as the extra cultural factor in the fruitless assumption that culture comes from culture". Namun, lingkungan lokal itu sendiri bagi Steward (1936) bukanlah faktor yang sangat menentukan. Menurut perspektif ekologi budaya unsur-unsur pokok adalah pola-pola perilaku (behavior patterns), yakni kerja (work), dan teknologi yang dipakai di dalam proses pengolahan atau pemanfaatan lingkungan. Lebih jauh lagi Febrianto (2016) mengatakan bahwa studi ekologi budaya pertama-tama adalah mengenai "the process of work, its organizations, its cycle and rhyoms and its situational modalities". Titik perhatiannya adalah pada analisis struktur sosial dan kebudayaan. Dengan demikian, perhatian baru diarahkan pada lingkungan bilamana lingkungan mempengaruhi atau menentukan pola-pola tingkah laku atau organisasi kerja.

Berdasarkan apa yang disampaikan oleh Febrianto (2016), ekologi budaya melihat pola perilaku adaptif dari manusia melalui kebudayaanya terhadap lingkungan alam di sekitarnya. Sebagaimana pendapat Abdoellah (2017) mengenai ekologi budaya, ia mengatakan faktor lingkungan tidak menentukan kemanusiaan. Bahkan, interaksi manusia dengan lingkungan melalui subsisten bekerja untuk menentukan dan memiliki pengaruh langsung terhadap lingkungan dalam tatanan sosial dan budaya. Selain itu, ekologi budaya mencoba menerangkan bagaimana populasi manusia beradaptasi terhadap kondisi lingkungan dengan memfokuskan perilaku dalam inti kebudayaan. Berdasarkan hal tersebut terlihat bahwa kebudayaan memiliki peranan penting untuk menentukan pengelolaan sumber daya alam di lingkungan sekitar, khususnya dalam proses adaptasi dan keberlangsungan dari alam itu sendiri melalui kearifan lokal.

\section{METODE PENELITIAN}

Dengan menggunakan penelitian deskriptif kualitatif dan metode deskriptif analitis. Suryani (2012: 74) mengatakan bahwa melalui metode tersebut dimaksudkan untuk mencatat, menuturkan, dan menafsirkan data melalui suatu proses pemahaman yang akan sangat bergantung pada keadaan data dan nilai bahan atau objek penelitian yang digarap. Dengan perkataan lain, metode ini berusaha untuk mengkaji teks dan konteks berdasarkan tafsiran dari satu sudut pandang keilmuan, yang dalam penelitian ini menggunakan pendekatan ekologi budaya. Tulisan ini bertujuan untuk dapat menggambarkan berbagai bentuk kearifan lokal melalui kebudayaannya yang dapat menjadi wawasan untuk pengembangan model pemberdayaan masyarakat.

\section{HASIL DAN PEMBAHASAN}

Dimensi kearifan lokal menurut Ife (2002) yang dikutip oleh Wibowo (2012: 27) terbagi ke dalam tiga dimensi. Pertama, dimensi pengetahuan lokal, yaitu di mana masyarakat setempat selalu memiliki pengetahuan lokal yang terkait dengan lingkungannya. Di sini ditunjukkan bahwa pengetahuan lokal dapat membedakan sumber daya alam yang dapat dikonsumsi atau dikembangbiakkan, dan sumber daya yang tidak dapat dikonsumsi atau berfungsi sebagai hiasan. Sehingga, tidak terjadi eksploitasi secara massif. Kedua, dimensi keterampilan lokal. Di sini keterampilan lokal digunakan sebagai kemampuan 
bertahan hidup (survival). Dimensi ini menerangkan bahwa kearifan lokal memberikan pengetahuan yang diturunkan secara turun temurun demi keberlangsungan generasi selanjutnya, baik menjadi peninggalan budaya benda (tangible heritage), maupun peninggalan budaya tak benda (intangible heritage). Ketiga, dimensi sumber daya lokal pada kepercayaan. Sumber daya lokal pada umumnya adalah sumber daya alam, yaitu sumber daya alam yang tidak dapat diperbarui dan dapat diperbarui yang terdapat di suatu daerah tertentu. Dalam dimensi ini, kearifan lokal melalui adat berperan untuk menjaga keberlangsungan alam dan lingkungannya dengan mengaturnya. Aturan tersebut biasanya berbentuk sebagai pantangan/larangan, sehingga pemanfaatan sumber daya alam dilaksanakan secara arif dan bijak.

Wibowo (2012) dalam artikel jurnalnya tentang kearifan lokal masyarakat Desa Colo dalam menjaga lingkungannya, mengemukakan bahwa masyarakat memiliki peran penting untuk melakukan tindakan pencegahan kerusakan lingkungan hidup. Proses pertahanan diri yang berupa kearifan lokal merupakan bentuk perwujudan dan peran masyarakat dalam upaya perlindungan daerah-daerah yang berpotensi sebagai tangkapan air yang berguna untuk kehidupan masyarakat desa. Adanya peranan perlindungan lingkungan yang dilakukan oleh masyarakat melalui kearifan lokal ecomistic, yaitu kegiatan yang menitikberatkan pada gerakan cinta lingkungan berkaitan dengan kearifan lokal berhubungan dengan kepercayaan masyarakat bahwa kekuatan di luar manusia yang turut menjaga kelestarian lingkungan. Oleh karena itu, kearifan lokal juga dapat diakatakan sebagai bagian yang sangat melekat pada masyarakat. Anggapan organisme flora tertentu memiliki khasiat dan manfaat untuk organisme lainnya, sehingga tidak terjadi pengeksploitasian secara massif. Selain itu, kearifan lokal juga dikatakan dapat menjembatani komunikasi antara manusia dengan alam melalui tradisi-tradisi semisal sedekah bumi.

Penelitian yang dilakukan oleh Wibowo (2012) memperlihatkan bahwa kearifan lokal tidak hanya menjaga keberlangsungan kehidupan manusia, melainkan kelestarian alam pun menjadi tanggung jawab dan bagian penting dalam kehidupan manusia yang dijaga melalui kearifan lokal. Oleh karena itu, jika kearifan lokal menjadi wawasan pokok dalam pemberdayaan masyarakat yang berbasis pengelolaan sumber daya alam, dapat dikatakan bahwa masyarakat dapat menjadi berdaya dalam jangka waktu yang panjang dikarenakan kondisi alamnya pun terjaga dengan baik.

Pengelolaan
sumber daya alam yang
didasarkan kepada memberikan keberlanjutan dari hutan itu sendiri. Hal tersebut tentunya menjadi bagian dari tujuan pembangunan berkelanjutan. Ungirwalu (2016) dalam penelitiannya melihat hubungan kearifan lokal dengan alam sebagai etnoekologi. Ia mengatakan bahwa terdapat 6 (enam) wujud etnoekologi dalam pemanfaatan dan pengelolaan sumber daya buah hitam bagi masyarakat adat Wandamen di Papua, yaitu sebagai sumber daya lokal, pengetahuan lokal, nilai lokal, keterampilan lokal, pengetahuan lokal, mekanisme pengambilan keputusan lokal, dan solidaritas kelompok lokal. Enam wujud tersebut dapat dikatakan sebagai konstruksi adaptif budaya lokal terhadap lingkungannya.

Sumber daya lokal dapat dikatakan sebagai kekayaan alam dari suatu lingkungan tertentu. Masyarakat adat cenderung hidup dengan melakukan adaptasi dengan lingkungan tempat tinggalnya, sehingga sumber daya alam lokal yang ada merupakan bagian dari pemenuhan kebutuhan biologisnya. Menurut Ungirwalu (2016) masyarakat Wandamen sendiri menjadikan buah hitam sebagai sumber makanan, selain sagu, umbi-umbian, dan sumber makanan pokok lainnya secara turun temurun. Berdasarkan hal tersebut, dapat dikatakan bahwa pengetahuan sumber daya alam lokal harus menjadi bagian dalam kegiatan pemberdayaan masyarakat. Dengan kata lain, sumber daya alam lokal menjadi sasaran pokok dalam pengembangan masyarakat di lokasi pemberdayaan. Model pemberdayaan sejatinya selain dapat memberdayakan masyarakat dan menjaga ekosistem atau kehidupan organisme lainnya di alam.

Selain sumber daya lokal, pengetahuan lokal, nilai lokal, keterampilan lokal, mekanisme pengambilan keputusan lokal, dan solidaritas kelompok lokal menjadi unsur penting dalam pemberdayaan. Hal-hal di atas merupakan modal sosial yang ada di masyarakat lokal, selain modal sumber daya alam. Modal sosial masyarakat lokal sendiri memiliki dua sisi, yaitu sisi positif dan negatif. Sisi positifnya adalah modal sosial yang dituangkan ke dalam adat istiadat dapat menjaga manusia dan lingkungan alamnya. Adapun sisi negatifnya, yaitu dapat menjadi hambatan dalam diseminasi ide dan pemikiran maju.

Turua (2014) menyebut masyarakat tersebut digolongkan ke dalam kelompok masyarakat miskin secara kultural. Oleh karena itu, dibutuhkan analisis sosial budaya yang kaitannya dengan kesmiskinan kultural, yaitu kebiasaan hidup dan budaya masyarakat yang merasa hidup berkecukupan dan tidak merasa kekurangan. Selain itu, Turua (2014) mengatakan bahwa aktivitas pertanian oleh petani asli Papua masih bersifat subsisten dengan jenis tanaman yang ditanam adalah tanaman yang dikonsumsi sendiri (keladi, 
ubijalar, singkong, pisang, pepaya, tomat dan rica). Hal ini berarti, masyarakat adat/lokal cenderung hidup untuk pemenuhan kebutuhan hidupnya sendiri tidak untuk mendapatkan pendapatan materi dari apa yang dikerjakan dalam kesehariannya.

Berdasarkan beberapa hasil penelitian di atas, kegiatan pemberdayaan seharusnya tidak berfokus kepada proses intervensi saja, melainkan dibutuhkan partisipasi aktif dari masyarakat lokal agar pemberdayaan tersebut berhasil dan berkelanjutan meski sudah tidak ada intervensi dari luar. Selain itu, partisipasi dapat menjadi salah satu cara untuk menumbuhkan rasa memiliki dari masyarakat akan program atau kegiatan pemberdayaan tersebut. Lebih dari itu, melalui partisipasi harapannya dapat mengubah pola pikir masyarakat lokal yang merasa hidupnya sudah cukup dan merasa tidak kekurangan untuk menjadi lebih terbuka dan berkembang untuk merespon perkembangan jaman.

Pengembangan masyarakat yang didasarkan kepada wawasan ekologi dapat memberikan sudut pandang baru mengenai model dan pola pemberdayaan masyarakat. Pemberdayaan masyarakat tidak selalu harus berhubungan dengan perkembangan sains dan teknologi. Pada kenyataannya, sains dan teknologi cenderung memberikan distorsi dan dampak negatif, yaitu kerusakan lingkungan. Mudhoffir (2011: 94) mengatakan bahwa, sains menjadi penyebab ancaman terhadap lingkungan karena kehadiran industri dan juga perkembangan teknologi rekayasa teknologi rekayasa genetik yang tidak terkendali. Namun, pada saat yang sama sains juga menjadi jalan untuk menghadapi ancaman-ancaman ekologis tersebut. Dengan perkataan lain, sains dan teknologi memang memiliki manfaat atau sisi positif terhadap pertumbuhan ekonomi dan kemajuan suatu daerah. Akan tetapi, di sisi lain dapat memberikan dampak negatif. Oleh karena itu, selain bersandar pada sains dan teknologi, kegiatan pemberdayaan memerlukan pengetahuan ekologi agar tercipta keseimbangan antara kesejahteraan manusia dengan keberlangsungan lingkungan hidup.

Dalam hal ini, pemberdayaan yang menggunakan sains dan teknologi perlu mengembangkan model baru agar tidak hanya fokus terhadap kesejahteraan manusianya saja, melainkan memerlukan sains dan teknologi yang dapat menjaga keberlangsungan lingkungan alam yang ada. Mungkin hal tersebut tentunya memerlukan proses yang panjang, karena perlunya riset yang cukup lama juga dana yang tidak sedikit. Akan tetapi, proses panjang tersebut tentunya akan terbayar dengan kelestarian alam dan lingkungan karena pengembangan model sains dan teknologi yang ramah lingkungan. Dengan kata lain, teknologi yang dimiliki oleh kebudayaan masyarakat lokal dapat menjadi acuan dalam pengembangan teknologi untuk kegiatan pemberdayaan. Sehingga, cara kerja masyarakat terhadap pengelolaan alam masih tetap sama tapi teknologi yang digunakan dapat mempermudah pengelolaan tersebut.

Seperti proses sains yang dilakukan oleh Marino pada tahun 2010 untuk menjernihkan air danau yang tercemar di Peru. Dengan menggunakan sains dan teknologi, Marino menciptakan penjernih air yang terbuat dari $100 \%$ bahan organik, dan bahkan aman untuk dikonsumsi oleh manusia. Hal tersebut memperlihatkan bahwa sains dan teknologi memberikan dampak positif terhadap lingkungan. Selain itu, beberapa peneliti di Jepang sudah mengembangkan dan bahkan membuktikan arang bambu dapat digunakan untuk berbagai hal, di antaranya sebagai media filtrasi penjernih air, kecantikan, deodorizer (penghilang bau) lemari pendingin/kulkas, dan bahkan menjadi bahan makanan. Padahal dalam kebudayaan masyarakat lokal di Indonesia, arang bambu sebagai media filtrasi air sudah dikenal dan digunakan cukup lama. Akan tetapi, hal itu belum dikembangkan dengan baik dan bahkan masyarakat lebih memilih teknologi modern yang dapat secara cepat menyelesaikan permasalahan, contohnya sanitasi air. Padahal, teknologi modern memerlukan energi lain dalam proses kerjanya. Oleh karena itu, melalui partisipasi dari masyarakat dengan nilai dan pengetahuan lokalnya, kegiatan pemberdayaan dapat menjadi bagian dari pengembangan teknologi yang berbasis kerifan lokal, selain pengembangan manusianya itu sendiri.

Perkembangan jaman melalui teknologi modern dan laju pertumbuhan penduduk yang cukup pesat membawa perubahan terhadap unsur sosialbudaya masyarakat. Terjadi pergeseran nilai budaya pada masyarakat, sehingga budaya gotong royong dan kecintaan kepada lingkungan mulai memudar. Selain itu, budaya asing yang masuk secara cepat sebagai modernisasi mengikis budaya lokal. Hal tersebut mengubah jiwa pluralis menjadi individualis, bahkan dewasa kini perkembangan teknologi modern telah menjadikan generasi muda apatis yang tidak begitu peduli dengan lingkungan sekitarnya. Pada titik ini, pembangunan manusia menjadi fokus penting dalam pembangunan untuk ketercapaian tujuan pembangunan yang berkelanjutan. Pemberdayaan masyarakat merupakan salah satu model yang dapat digunakan untuk pembangunan manusia itu sendiri. Jadi, tidak hanya mengenai pengelolaan sumber daya alam, salah satu kegiatan pemberdayaan masyarakat yaitu melakukan pembangunan terhadap manusia dengan cara membantu menyadarkan dan memberikan 
bantuan solusi bagi masyarakat mengenai permasalahan yang ada di lingkungan tempat tinggalnya, seperti permasalahan limbah sampah.

Sebelum berkembangnya teknologi modern, industrialisasi, dan pertumbuhan penduduk yang pesat, limbah sampah dapat dikatakan bukan sebuah permasalahan. Produk-produk rumah tangga terbuat dari bahan-bahan yang ramah lingkungan karena terbuat dari bahan organik yang dapat terurai, misalkan mangkok dan piring yang menggunakan kayu atau batok kelapa, tempat minum yang terbuat dari potongan bambu, atau bungkus makanan yang terbuat dari dedaunan. Tidak hanya dapat terurai, beberapa peralatan tersebut dapat digunakan berkalikali bukan sekali pakai, sehingga sampah belum menjadi masalah di lingkungan. Akan tetapi, dewasa kini dengan berkembangnya teknologi modern, industrialisasi, dan laju pertumbuhan penduduk yang sangat pesat menimbulkan permasalahan baru, yaitu sampah.

Wardi (2011: 168) mengatakan bahwa di Bali pengelolaan sampah sudah dilaksanakan sejak masa silam. Menurutnya, pengelolaan sampah organik sudah dikelola secara tradisional, yaitu dengan cara menjadikan sebagai makanan ternak babi dan sebagai pupuk hijau dan ada juga yang melakukan pembakaran terhadap sampah tersebut. Selain itu, pekarangan di Bali pada umumnya dibagi menjadi 3 bagian atau disebut dengan tri mandala, yaitu utama mandala, madya mandala, dan nista mandala. Bagian nista mandala merupakan pekarangan yang berada paling hilir, yang biasanya dimanfaatkan sebagai tempat mengelola sampah, tempat beternak, dan budidaya buah-buahan dan beragam jenis pepohonan yang biasanya digunakan sebagai bahan untuk membuat bangunan. Dikatakan juga, bahwa pengelolaan sampah secara tradisional tersebut mendatangkan manfaat ganda, di samping volume sampah dapat dikurangi, ternak hewan dapat berkembang relatif cepat, dan lahan garapan di daerah tersebut menjadi subur.

Sistem pengelolaan sampah di Bali tersebut tidak jauh berbeda dengan sistem agroforesti tradisional di Jawa Barat. Abdoellah (2017: 113) yang mengutip Soemarwoto (1984) mengemukakan bahwa sistem wanatani tradisional, seperti sistem pekarangan dan kebun talun banyak ditemukan di Jawa Barat. Pernyataan tersebut juga disampaikan oleh Terra (1953) dan Wiersum (1982) dalam Abdoellah (2017: 113) bahwa kedua sistem tersebut telah dipraktekkan sejak lama secara turun temurun. Selain itu, kedua sistem tersebut dikatakan berpotensi untuk mengatasi kelanjutan menurunnya kualitas lingkungan hidup. Tidak hanya itu, sistem tersebut juga melekat pada ekosistem pedesaan yang memiliki beberapa fungsi yaitu ekonomis, sosial, dan ekologis. Berdasarakan hal tersebut, kearifan lokal melalui cara kerja kebudayaan sudah lama membangun pola hidup yang tidak hanya menguntungkan manusianya, melainkan juga kelangsungan lingkungan hidup di sekitarnya.

Abdoellah (2017) mengatakan bahwa dari fungsi ekonomi sistem agroforesti di pedesaan di Jawa Barat tidak hanya menghasilkan bahan pangan, melainkan merupakan salah satu sumber pendapatan rumah tangga. Selain itu, pekarangan dan kebun talun juga berfungsi sebagai sumber kayu bakar, sehingga mengurangi ketergantungan masyarakat terhadap hutan alam. Di samping fungsi ekonomi, pekarangan dan kebun talun juga memiliki fungsi sosial. Hal itu terlihat dari kebiasaan saling berbagi antar masyarakat. Bagi masyarakat miskin yang tidak mempunyai lahan, mereka cenderung mengambil daun, ranting, maupun dahan yang jatuh di kebun talun milik orang untuk dijadikan kayu bakar, tanpa harus minta izin dari pemiliknya. Selain itu tanaman obat maupun buah-buahan dapat dinikmati bersama. Budaya saling berbagi ini membantu menjaga dan memperkuat jejaring dan ikatan sosial dan bahwa mampu menguatkan komunitas untuk bertahan dari guncangan-guncangan sosial dan ekonomi. Dengan perkataan lain, budaya tersebut dapat menjadi perekat hubungan sosial masyarakat di perdesaan.

Selain itu, dikatakan juga bahwa sistem wanatani tradisional juga memiliki fungsi ekologi, yaitu dapat memelihara kesuburan tanah, megendalikan erosi, melindungi daerah aliran sungai secara umum, dan memelihara iklim secara mikro. Abdoellah (2017), juga mengatakan bahwa selain berperan dalam memelihara keanekaragaman hayati, secara global sistem ini merupakan tempat penyimpanan karbon. Berdasarkan hal tersebut, jelas terlihat bahwa kearifan lokal memiliki manfaat untuk kelangsungan hidup manusia dan alamnya. Maka, sangat mugkin jika ekologi budaya menjadi wawasan dalam model pemberdayaan masyarakat.

Akan tetapi, dewasa ini konsep wanatani, baik di Bali maupun di Jawa Barat tidak akan berfungsi secara penuh. Pesatnya perkembangan teknologi modern telah menciptakan limbah-limbah sampah yang sulit terurai. Selain itu, industrialiasi menciptakan limbah-limbah baru yang bukan hanya tidak dapat terurai. Lebih dari itu, limbah kimiawi juga mencemari Daerah Aliran Sungai (DAS), sehingga kualitas air menjadi buruk. Hal tersebut juga didukung oleh laju pertumbuhan penduduk yang cepat, sehingga tidak banyak lahan kosong dan lingkungan rumah sudah saling berdempetan satu sama lain. Meskipun begitu, permasalahan tersebut tidak sepenuhnya menjadi sulit untuk ditanggulangi dan ditangani. Pemberdayaan dapat menciptakan peluang lain baik 
itu melalui sains dan teknologi maupun proses kreatif. Semisal yang dilakukan oleh YPBB Bandung maupun Bank Sampah Sungai Cisadane dalam pendampingan pengelolaan limbah rumah tangga. Dalam pengelolaan programnya, mereka memadukan konsep kearifan lokal dengan kreatifitas pada pengelolaan sampah.

\section{PENUTUP}

\section{Kesimpulan}

Ekologi budaya masyarakat lokal melalui kearifan lokalnya mengatur pola perilaku masyarakat. Pola perilaku masyarakat yang didasarkan kepada kearifan lokal cenderung lebih ekologis dibandingkan dengan masyarakat modern yang tidak menggunakan kearifan lokal dalam kehidupannya. Kearifan lokal tidak hanya berperan sebagai pengontrol kehidupan manusia secara individu. Lebih jauh lagi sudah memikirkan kelangsungan manusia lainnya di daerah tersebut dan juga keberlangsungan lingkungan alam di sekitarnya, yang mana hal tersebut merupakan bagian dari tujuan pembangungan yang berkelanjutan.

Dalam tulisan ini, didapatkan simpulan bahwa nilai-nilai kebudayaan di Indonesia cenderung ekosentris dan biosentris, sehingga dapat dikatakan sebagai deep ecology (ekologi yang dalam/pekat). Hal tersebut terlihat dari pola perilaku masyarakat yang memercayai ada kekuatan lain yang turut menjaga lingkungan di sekitar tempat hidup mereka. Alam dianggap sebagai bagian dari mereka, bukan sebagai organisme yang berada di luar ekosistem. Selain itu, ditunjukkan juga nila-nilai kebudayaan mengatur pengelolaan sumberdaya alam dengan arif. Tulisan ini juga menunjukkan bahwa kearifan lokal sebagai ekologi budaya merupakan wawasan penting dalam kegiatan pengembangan masyarakat karena tidak hanya membentuk kemandirian dan menciptakan kesejahteraan, tetapi juga merupakan pengejawantahan dari pembangungan berkelanjutan.

\section{REFERENSI}

Abdoellah, O. S. 2017. Ekologi Manusia dan Pembangunan Berkelanjutan. Jakarta: Gramedia.

Febrianto, A. Wirdanengsih. 2016. Handout Mata Kuliah Antropologi Ekologi. Diakses pada tanggal 30 Juni 2020, pukul 19.37 WIB.

Gea, A. A. 2002. Relasi dengan Diri Sendiri. Jakarta: Elex Media Komputindo.

Ife, J. 1995. Community Development, Creating Community Alternatives: Vision, Analysis and Practice. Sydney: Longman Australia Pty Ltd.

Jamaluddin, A. N. 2016. Sosiologi Pembangunan. Bandung: Pustaka Setia
Mudhoffir, A. M. 2011. "Krisis Ekologi dan Ancaman bagi Kapitalisme." MASYARAKAT, Jurnal Sosiologi, Vol. 16, No. 1, Januari 2011: 93102.

Suharto, E. 2009. Membangun Masyarakat Memberdayakan Rakyat. Bandung: Reflika Aditama

Suryani, E. (2012). Filologi. Bogor: Ghalia

Turua, U., dkk. 2014. Ekologi dan Budaya Petani Asli Papua dalam Usaha Tani di Kabupten Keerom. Sosiohumaniora, Vol. 16 No. 3, 2014: 234-241.

Ungirwalu, A., dkk. 2016. Pengelolaan Adaptif Pemanfaatan Buah Hitam (Haplolobus monticola Blumea) Etnis Wandamen-Papua (Adaptive Management Utilization of Black Fruit (Haplolobus monticola Blumea) Ethnic Wandamen-Papua). Jurnal Manusia dan Lingkungan, Vol. 23 No.2, 2016: 266-275.

Wardi, I. N. 2011. Pengelolaan Sampah Berbasis Sosial Budaya: Upaya Mengatasi MasalahLingkungan di Bali. Jurnal Bumi Lestari, Volume 11 No. 1, 2011: 167 - 177.

Wibowo, H., dkk. 2012. Kearifan Lokal dalam Menjaga Lingkungan Hidup (Studi Kasus Masyarakat di Desa Colo Kecamatan Dawe Kabupaten Kudus. Jurnal of Educational Social Studies, Vol. 1 No. 1, 2012: 26-30. 